\title{
EVALUASI KEBIJAKAN MANAJEMEN ASN DITINJAU DARI ASPEK PERENCANAAN, PEREKRUTAN DAN PENGEMBANGAN KOMPETENSI DI KEMENTERIAN PERHUBUNGAN REPUBLIK INDONESIA
}

\author{
Robby Kurniawan ${ }^{1}$, Aries Djaenuri², Hadi Prabowo ${ }^{3}$, Sampara Lukman $^{4}$ \\ ${ }^{1,2,3,4}$ Institut Pemerintahan Dalam Negeri (IPDN) \\ Email: robby.biroren@gmail.com
}

\begin{abstract}
Abstrak
Penelitian ini bertujuan untuk mengevaluasi kebijakan manajemen ASN pada Kementerian Perhubungan Republik Indonesia ditinjau dari segi perencanaan, perekrutan dan pengembangan potensi. Pendekatan yang digunakan dalam penelitian ini adalah menggunakan Soft Systems Methodology (SSM) berbasis action research sebagai metode penelitian dengan pendekatan berpikir sistem. Pemilihan metode penelitan ini dilakukan mengingat bahwa manajemen ASN adalah merupakan Human Activity System dengan berbagai problem yang melibatkan banyak instansi serta terdapat berbagai kebijakan peraturan perundang-undangan yang digunakan. Hasil penelitian menemukan situasi problematik dalam kebijakan manajemen ASN dalam aspek perencanaan, rekrutmen, dan pengembangan kompetensi. Evaluasi manajemen memakai 7 dimensi dan indikator yang meliputi: kebijakan, perumusannya, dan penyebarannya, konteks sosial, politik, dan ekonomi, kepemimpinan untuk implementasi kebijakan, keterlibatan pemangku kepentingan dalam implementasi kebijakan, perencanaan implementasi dan mobilisasi sumber daya, operasi dan layanan, dan umpan balik tentang kemajuan dan hasil.
\end{abstract}

Kata Kunci: Aparatur Sipil Negara, Manajemen, Perencanaan, Perekrutan, Kompetensi.

\section{Abstract}

This study aims to evaluate ASN management policies at the Ministry of Transportation in terms of planning, recruitment and potential development. The approach used in this study is to use action research-based Soft Systems Methodology (SSM) as a research method with a systems thinking approach. The selection of this research method was carried out considering that ASN management is a Human Activity System with various problems involving many agencies and there are various laws and regulations that are used. The results of the study found a problematic situation in ASN management policies in the aspects of planning, recruitment, and competency development. Management evaluation uses 7 dimensions and indicators which include: policy, its formulation, and dissemination, social, political and economic context, leadership for policy implementation, stakeholder involvement in policy implementation, planning implementation and resource mobilization, operations and services, and feedback on progress and results.

Keywords: State Civil Apparatus, Management, Planning, Recruitment, Competence.

\section{A. PENDAHULUAN}

Penyelenggaraan pelayanan publik di Indonesia masih memiliki berbagai permasalahan yang perlu diselesaikan, walaupun sudah ada peningkatan yang cukup signifikan dalam pelaksnaannya namun masih tertingggal dengan negara lain di Asia bila 
ARTIKEL

merujuk berbagai indikator global. Salah satu hal yang dapat mengangkat kinerja pelayanan publik di Indonesia adalah aspek manajemen aparatur sipil negara (ASN). Salah satu yang menjadi referensi misalnya menurut Friedman (2007), menjelaskan bahwa manajemen sumber daya manusia dianggap sebagai bidang manajemen yang mampu membawa kontribusi strategis bagi organisasi. Manajemen sumber daya manusia berkaitan erat dengan penggunaan aset sumber daya manusia untuk pencapaian tujuan organisasi dan kelangsungan serta keberhasilan organisasi (Becker dkk., 2001; Stavrou \& Brewster, 2005; Baron \& Armstrong, 2007). Organisasi akan mendapatkan keuntungan dari mengadopsi 'praktik terbaik' dalam cara mereka mengelola sumber daya manusia (Becker, dkk., 2001). Bahkan, untuk memaksimalkan utilitas sumber daya manusia, seringkali diperlukan bagi suatu organisasi untuk memanfaatkan 'praktik terbaik' dari manajemen sumber daya manusia (Handoko, 2001; Bushardt dkk., 2011).

Saat ini, manajemen sumber daya manusia sangat dituntut untuk memberikan kontribusi yang signifikan bagi organisasi berdasarkan fungsi-fungsi yang berhubungan dengan cara bagaimana para pekerja tertarik, dikembangkan, dinilai dan dikelola dalam organisasi dengan tingkat efektivitas yang tinggi (Ahmadi dkk., 2012; Basuki, 2006). Menurut perspektif ini, poin kuncinya adalah organisasi memiliki praktik-praktik yang efektif dalam manajemen sumber daya manusia (Fathoni, 2019; Morley dkk., 2006). Oleh karena itu, menurut Becker \& Gerhart (1996), manajemen sumber daya manusia yang efektif dapat menciptakan keunggulan kompetitif, nilai yang unik dan tidak mudah ditiru oleh organisasi lain.

Berkaitan dengan manajemen sumber daya manusia atau ASN jika konteknya adalah organisasi sektor publik, Indonesia masih memiliki pekerjaan rumah yang cukup besar. Hal yang sering disoroti terkait rendahnya kualitas ASN. Hal ini menurut beberapa pakar disebabkan sebagai akibat dari rekrutmen, pengangkatan dalam jabatan dan promosi yang belum didasarkan pada pertimbangan yang obyektif (Hasibuan, 2005; Prasojo, 2006). Selain itu, maraknya praktek spoil system dalam manajemen ASN, dimana jabatan diberikan kepada pejabat yang ada hubungan dengan partai yang berkuasa (Blunt, dkk., 2012; Aspinal, 2019). Praktek seperti itu sudah ada sejak lama namun semakin berkembang sejak diberlakukannya pemilihan umum langsung di daerah. Meningkatnya praktek spoil system merupakan salah satu pendorong tingginya tingkat korupsi di kalangan politisi dan pegawai negeri sipil di daerah (KASN, 2018).

Manajemen ASN dipandang sebagai sebuah sistem yang saling terkait mulai dari perencanaan, rekrutmen, pengembangan kompetensi, penilaian kinerja, promosi, rotasi, dan 
ARTIKEL

karir, hingga purnabhakti (Indonesia, 2017; Oktarina \& Mustam, 2018). Akan tetapi, pada implementasinya terdapat beberapa permasalahan yang terjadi berkaitan dengan manajemen ASN tersebut sehingga mempengaruhi kinerja pelayanan publik di Indonesia. Dalam menyikapi pentingnya peran SDM tersebut, pemerintah melakukan upaya reformasi birokrasi yang salah satunya menyasar perubahan pada area SDM. Berbagai persoalan yang telah dijelaskan di atas pada ASN dan tantangan yang harus dihadapi dalam konteks global membuat pemerintah melakukan pembaharuan sistem kepegawaian dengan ditetapkannya Undang-Undang No. 5 Tahun 2014 tentang Aparatur Sipil Negara. Harapannya, terjadi perubahan sistem kepegawaian Indonesia dari mengedepankan peraturan (rule based) ke arah birokrasi yang berbasis kinerja (performance based), kemudian mencapai dynamic governance pada tahun 2025 (KemenPANRB, 2013).

Undang-Undang No. 5 Tahun 2014 tentang ASN seolah ingin memberikan harapan baru agar pengelolaan ASN dapat dijalankan sesuai dengan sistem merit. Berbagai catatan di atas seolah ingin dijawab dengan adanya UU No. 5 Tahun 2014 tentang ASN tersebut. Manajemen ASN yang harus berdasarkan sistem merit diamanatkan pada 14 (empat belas) aspek, yaitu (1) penyusunan dan penetapan kebutuhan, (2) pengadaan, (3) pangkat dan jabatan, (4) pengembangan karier, (5) pola karier, (6) promosi, (7) mutasi, (8) penilaian kinerja, (9) penggajian dan tunjangan, (10), penghargaan, (11) disiplin, (12) pemberhentian, (13) jaminan pensiun dan jaminan hari tua, dan (14) perlindungan. Perubahan pada manajemen ASN selaku amanat UU No. 5 Tahun 2014 ini sejatinya juga harus dapat berkontribusi pada pencapaian sasaran pembangunan nasional yang diprioritaskan.

Peningkatan manajemen ASN di Kementerian Perhubungan berarti mendorong terwujudnya tujuan dan sasaran pembangunan Kementerian Perhubungan pada tahun 20202024 berupa (1) meningkatnya aksesibilitas masyarakat terhadap jasa layanan transportasi, (2) meningkatnya kinerja layanan transportasi, (3) Berkurangnya rasio kejadian kecelakaan dan gangguan keamanan dalam setiap pelayanan jasa transportasi, (4) tercapainya restrukturisasi dan reformasi birokrasi di Kementerian Perhubungan, dan (5) terwujudnya penggunaan teknologi transportasi yang ramah lingkungan dalam layanan transportasi.

Oleh karena itu, kajian mengenai evaluasi kebijakan manajemen aparatur sipil negara menjadi menarik untuk dilakukan dengan mengambil objek penelitian di Kementerian Perhubungan. Selanjutnya, aspek manajemen ASN yang perlu dikaji menjadi persoalan berikutnya. Dari 6 (enam) aspek manajemen ASN yang perlu dilakukan oleh pemerintah, penelitian ini hanya akan fokus pada 3 (tiga) aspek saja yang menurut peneliti sangat penting 
ARTIKEL

$\overline{\text { berkaitan dengan peningkatan kualitas ASN di birokrasi, yaitu aspek perencanaan, rekrutmen, }}$ dan pengembangan kompetensi ASN.

\section{B. METODE}

Pendekatan yang digunakan dalam penelitian ini adalah menggunakan Soft Systems Methodology (SSM) berbasis action research (Uchiyama, 2009) sebagai metode penelitian dengan pendekatan berpikir sistem (Checkland, 1981). SSM didasarkan pada gagasan bahwa faktor-faktor manusia dan organisasi tidak dapat dipisahkan dari penyelesaian problem. Pemilihan metode penelitan ini dilakukan mengingat bahwa manajemen ASN adalah merupakan Human Activity System dengan berbagai problem yang melibatkan banyak instansi serta terdapat berbagai kebijakan peraturan perundang-undangan yang digunakan.

Soft Systems Methodology (SSM) yang termasuk dalam penelitian tindakan dapat digunakan untuk keperluan research interest, problem solving interest, atau bisa juga keduanya (dual imperative) (Hardjosoekarto, 2012; McKay \& Marshall, 2001). Research Interest berangkat dari factual issue dalam suatu teori tertentu (theoritical issue), sedangkan problem solving interest berangkat dari factual issue yang terjadi dalam real world (Hardjosoekarto, 2012). Saat ini telah berkembang penelitian SSM yang berada diantara kutub Research Interest dan problem solving interest. Dalam penelitian ini mengambil pada bagian kedua kutub tersebut karena penelitian ini berangkat dari factual issue yang terjadi di dunia nyata.

\section{HASIL DAN PEMBAHASAN}

Merujuk pada metode SSM, peneliti melakukan intervensi awal dengan menelusuri dan memahami situasi problematik perencanaan, rekrutmen dan pengembangan kompetensi di Kementerian Perhubungan. Proses penelusuran dan pemahaman situasi problematik dilakukan dengan merujuk pada teknik pengumpulan data dan teknik analisis data yang diaplikasikan. Dengan wawancara mendalam, FGD, dan diskusi informal, peneliti menelusuri berbagai situasi problematik ketiga aspek manajemen ASN tersebut. Kemudian, peneliti menganalisis data yang telah dikumpulkan tersebut, sehingga memunculkan pemahaman yang komprehensif mengenai situasi problematik terkait ketiga aspek manajemen ASN tersebut.

Selain itu, proses intervensi berjalan lebih optimal berhubung peneliti menjadi bagian yang tidak terpisahkan dalam kerangka kelembagaan manajemen ASN di Kementerian Perhubungan. Hal ini menyebabkan intervensi yang dilakukan menghasilkan penelusuran dan 
ARTIKEL

pemahaman yang lebih mendalam. Dari intervensi ini, peneliti menghasilkan identifikasi masalah yang lebih terstruktur. Hasil identifikasi masalah tersebut menjelaskan aspek sosial, aspek politik, dan situasi problematik pada ketiga aspek manajemen ASN yang dikaji.

\section{Evaluasi Aspek Perencanaan ASN di Kementerian Perhubungan}

Sebagai standar evaluasi pada aspek perencanaan di Kementerian Perhubungan, Republik Indonesia penelitian ini menggunakan 7 dimensi dan indikator. Jika menggunakan istilah yang ada dalam metode SSM, apa yang ada pada 7 dimensi dan indikator merupakan model konseptual dari aspek perencanaan di Kementerian Perhubungan. Nantinya, akan dijelaskan satu per satu dari dimensi yang digunakan untuk mengevaluasi aspek perencanaan ASN di Kementerian Perhubungan.

Pertama, evaluasi aspek perencanaan ASN di Kementerian Perhubungan dari dimensi kebijakan, perumusannya, dan penyebarannya. Beberapa poin penting yang dievaluasi menurut dimensi ini adalah apakah tujuan, sasaran, dan strategi kebijakan terkait aspek perencanaan ASN di Kementerian Perhubungan itu jelas dan sesuai dengan masalah yang harus ditangani oleh kebijakan? Apakah pemangku kepentingan utama menyetujui tujuan dan strategi aspek perencanaan ASN di Kementerian Perhubungan? Apakah kebijakan telah disebarluaskan ke dan dipahami oleh mereka yang bertanggung jawab untuk mengimplementasikannya di Kementerian Perhubungan?.

Secara nasional, kebijakan mengenai perencanaan ASN harus menyesuaikan arah pembangunan nasional. Dalam hal ini, Kementerian Perhubungan diharuskan untuk menyesuaikan Analisis Beban Kerja (ABK) dengan Rencana Strategis Kementerian Perhubungan itu sendiri. Selain itu, kebutuhan pegawai baru jika diperlukan harus didasarkan pada ABK.

Jika melihat Rencana Strategis Kementerian Perhubungan Tahun 2015-2019 terlihat bahwa secara ekplisit dimunculkan sasaran agar terpenuhinya SDM transportasi baik dari segi jumlah maupun kompetensi sesuai dengan kebutuhan. Strategi yang ditempuh berupa menyusun Man Power Planning SDM transportasi, menyusun Training Needs Analysis (TNA) SDM transportasi, mengembangkan kapasitas diklat SDM transportasi, menata regulasi penyelenggaraan diklat SDM transportasi, meningkatkan tata kelola diklat dan kualitas lulusan, dan meningkatkan penyerapan lulusan diklat transportasi. Apabila melihat arah, sasaran, dan strategi yang ditetapkan oleh Kementerian Perhubungan tersebut, maka dalam konteks aspek perencanaan ASN hal itu sudah jelas dan sesuai dengan masalah yang harus ditangani oleh kebijakan. Arah, sasaran, dan strategi ini disetujui oleh pemangku 
ARTIKEL

kepentingan di Kementerian Perhubungan dengan disepakatinya Rencana Strategis Kementerian Perhubungan Tahun 2015-2019.

Kedua, evaluasi aspek perencanaan ASN di Kementerian Perhubungan dari dimensi konteks sosial, politik, dan ekonomi. Dimensi ini mengevaluasi perihal faktor sosial, politik, dan ekonomi di luar proses kebijakan yang ada di Kementerian Perhubungan yang dapat meningkatkan atau menghambat implementasi yang efektif terkait aspek perencanaan ASN.

Konteks sosial pada periode 2015-2019 menunjukkan adanya perkembangan teknologi yang mengubah perilaku masyarakat. Banyaknya generasi milenial mempengaruhi aspek perencanaan ASN di Kementerian Perhubungan. Sementara itu, terkait konteks politik, meskipun UU ASN telah disahkan, aturan turunannya membutuhkan proses yang panjang. Bahkan, Peraturan Pemerintah yang semula berjumlah 19 PP kemudian dikerucutkan hanya menjadi 6 PP. Dalam implementasinya, dalam periode 2015-2019 baru terbit 1 (satu) PP yaitu tentang manajemen PNS. Regulasi yang belum utuh ini membuat aspek perencanaan ASN terlihat sporadis. Adapun terkait konteks ekonomi, terdapat prioritas pembangunan infrastruktur dari pemerintah yang mempengaruhi aspek perencanaan ASN. Apalagi, Kementerian Perhubungan menjadi salah satu instansi yang harus mendukung prioritas pembangunan infrastruktur tersebut. Dalam konteks mengisi jabatan yang kosong dan mengembangkan SDM yang dimiliki sehingga sesuai dengan arah pembangunan nasional menjadi hal yang turut mempengaruhi aspek perencanaan ASN di Kementerian Perhubungan.

Ketiga, evaluasi aspek perencanaan ASN di Kementerian Perhubungan dari dimensi kepemimpinan untuk implementasi kebijakan. Hal yang dievaluasi menurut dimensi ini adalah kepemimpinan dan komitmen terkait aspek perencanaan ASN di Kementerian Perhubungan. Merujuk pada hal tersebut, kepemimpinan dan komitmen dalam mengembangkan kompetensi ASN di Kementerian Perhubungan terlihat menonjol dibandingkan dengan aspek yang lainnya. Berbagai program pendidikan dan pelatihan diselenggarakan melalui berbagai format pada periode tahun 2015-2019.

Keempat, evaluasi aspek perencanaan ASN di Kementerian Perhubungan dari dimensi keterlibatan pemangku kepentingan dalam implementasi kebijakan. Hal yang disorot menurut dimensi ini adalah keterlibatan pemangku kepentingan dalam implementasi kebijakan aspek perencanaan dan sifat dari hubungan dan kolaborasi di antara para pemangku kepentingan yang berbeda. Keterlibatan pemangku kepentingan terlihat dalam penyusunan Anjab dan ABK. Keterlibatan setiap unit kerja dalam menyusun Anjab dan ABK dilakukan dengan 2 (dua) cara, yaitu secara langsung atau tidak langsung. Secara langsung maksudnya dilibatkan dalam rapat-rapat penyusunan Anjab dan ABK. Secara tidak langsung maksudnya hanya 
ARTIKEL

memberikan data-data yang dibutuhkan. Selain itu, keterlibatan para pemangku kepentingan juga teridentifikasi dari proses mengoordinasikan kembali hasil Anjab dan ABK yang telah disusun untuk mendapatkan persetujuan.

Kelima, evaluasi aspek perencanaan ASN dari dimensi perencanaan implementasi dan mobilisasi sumber daya. Hal yang dievaluasi dari dimensi ini berkaitan dengan pertimbangan terhadap perencanaan, sumber daya, dan kapasitas yang diperlukan untuk memfasilitasi implementasi kebijakan terkait aspek perencanaan ASN. UU ASN pada tahun 2015 merupakan undang-undang baru yang harus diimplementasikan. Dalam implementasi aspek perencanaan ASN, terdapat adaptasi yang dilakukan oleh Kementerian Perhubungan. Salah satu yang perlu disesuaikan berkaitan dengan administrasi kepegawaian. Oleh karena itu, dalam perencanaan ASN di Kementerian Perhubungan, bimbingan teknis terkait administrasi kepegawian yang baru terus dilakukan dalam kurun kurang lebih 2 (dua) tahun. Tentunya, hal tersebut merupakan bentuk penyesuaian terhadap perlunya keterampilan dan pelatihan baru untuk menerapkan kebijakan yang tergolong baru. Dari segi pendanaan pun dipastikan teralokasi untuk mendanai inisiatif baru dalam aspek perencanaan ASN di Kementerian Perhubungan.

Keenam, evaluasi aspek perencanaan ASN dari dimensi operasi dan layanan. Hal yang disorot dari dimensi ini adalah apakah terdapat mekanisme koordinasi, sistem operasional, dan kapasitas individu dan organisasi yang direncanakan di Kementerian Perhubungan? Apa ada perubahan positif sebagai hasil dari penerapan kebijakan aspek perencanaan di Kementerian Perhubungan? Apa saja tantangan dalam koordinasi, sistem operasional, dan kapasitas individu dan organisasi dalam aspek perencanaan ASN di Kementerian Perhubungan?

Ketujuh, evaluasi aspek perencanaan ASN di Kementerian Perhubungan dari dimensi umpan balik tentang kemajuan dan hasil. Hal yang krusial dari aspek perencanaan ASN adalah dokumen Anjab dan ABK. Di Kementerian Perhubungan, pasca terbitnya UU ASN, baru pada tahun 2016 terumuskan dokumen Anjab dan ABK di Unit Eselon I dan tahun 2017 terumuskan di lingkungan Unit Pelaksana Teknis pada tahun 2016.

\section{Evaluasi Aspek Rekrutmen ASN di Kementerian Perhubungan}

Sebagai standar evaluasi pada aspek rekrutmen di Kementerian Perhubungan, penelitian ini menggunakan 7 dimensi dan indikator yang sekaligus merupakan model konseptual jika menggunakan istilah yang ada dalam metode SSM. Nantinya, akan dijelaskan 
ARTIKEL

satu per satu dari dimensi yang digunakan untuk mengevaluasi aspek rekrutmen ASN di Kementerian Perhubungan.

Terdapat variasi jalur rekrutmen pegawai yang ada di Kementerian Perhubungan untuk menjadi ASN. Beberapa jalur yang dapat berlaku di Kementerian Perhubungan adalah rekrutmen CPNS, Penerimaan Calon Taruna yang berada di bawah kewenangan BPSDM Perhubungan, penerimaan Pegawai Pemerintah dengan Perjanjian Kerja (PPPK), dan seleksi terbuka untuk Jabatan Pimpinan Tinggi yang kosong.

\section{a. Evaluasi Rekrutmen CPNS}

Pertama, evaluasi aspek rekrutmen CPNS di Kementerian Perhubungan dari dimensi kebijakan, perumusannya, dan penyebarannya. Terkait dimensi ini, Kementerian Perhubungan hanya melaksanakan kebijakan khususnya yang dibuat oleh Kementerian Pendayagunaan Aparatur Negara dan Reformasi Birokrasi. Kebijakan formasi yang terpusat tersebut hanya memberikan ruang bagi Kementerian Perhubungan untuk mengusulkan formasi. Penetapan formasi berada di bawah wewenang KemenPANRB. Pada setiap tahunnya, KemenPANRB akan mengeluarkan peraturan menteri yang mengatur hal tersebut. sebagai contoh, pada tahun 2018 diterbitkan Peraturan Menteri Pendayagunaan Aparatur dan Reformasi Birokrasi Nomor 36 Tahun 2018 tentang Kriteria Penetapan Kebutuhan Pegawai Negeri Sipil dan Pelaksanaan Seleksi Calon Pegawai Negeri Sipil Tahun 2018.

Anjab dan ABK yang telah disusun pada aspek perencanaan ASN dijadikan sebagai dasar bagi Kementerian Perhubungan untuk mengusulkan formasi CPNS ke KemenPANRB. Hal yang biasanya menjadi bias adalah penentuan formasi yang ditetapkan oleh KemenPANRB dengan kebutuhan riil pegawai di Kementerian Perhubungan.

Kedua, evaluasi aspek rekrutmen CPNS di Kementerian Perhubungan dari dimensi konteks sosial, politik, dan ekonomi. Pelaksanaan seleksi CPNS yang terpusat, ketat, dan mengaplikasikan teknologi menjadikan seleksi CPNS pasca terbitnya UU ASN berbeda dengan sebelum-sebelumnya. Setidaknya, dengan sistem seleksi demikian, praktik korupsi, kolusi, dan nepotisme dapat diminimalisir.

Dalam konteks ekonomi, terdapat kasus pada seleksi CPNS tahun 2018 dan 2019 yang mana Kementerian Perhubungan mendapat mandat untuk menerima lulusan STAN. Sesuai Keputusan Menteri Pendayagunaan Aparatur Negara dan Reformasi Birokrasi Nomor 657 Tahun 2018 tentang Penetapan Kebutuhan Pegawai Negeri Sipil Negara di lingkungan Kementerian Perhubungan dari Lulusan Politeknik Keuangan Negara STAN Tahun Anggaran 2018, Kementerian Perhubungan mendapatkan alokasi formasi sejumlah 37 formasi. Adapun untuk alokasi anggaran tahun 2019, sesuai Keputusan Menteri 
ARTIKEL

$\overline{\text { Pendayagunaan Aparatur Negara dan Reformasi Birokrasi Nomor } 878 \text { Tahun } 2019 \text { tentang }}$ Penetapan Kebutuhan Pegawai Negeri Sipil Dari Lulusan Politeknik Keuangan Negara STAN di Lingkungan Kementerian Perhubungan Tahun Anggaran 2019, Kementerian Perhubungan mendapatkan alokasi formasi sejumlah 69 formasi.

Ketiga, evaluasi aspek rekrutmen CPNS di Kementerian Perhubungan dari dimensi kepemimpinan untuk implementasi kebijakan. Kepemimpinan dan komitmen terkait rekrutmen CPNS di Kementerian Perhubungan terlihat dengan mendukung seluruh proses seleksi yang dilakukan secara objektif. Jika melihat komitmen kebijakannya, maka terdapat Peraturan Menteri Perhubungan No. 128 Tahun 2016 Pengangkatan Pegawai Negeri Sipil Dalam Jabatan di Lingkungan Kementerian Perhubungan, Peraturan Menteri Perhubungan No. 21 Tahun 2017 tentang Perubahan atas Peraturan Menteri Perhubungan Nomor PM 128 Tahun 2016 tentang Pengangkatan Pegawai Negeri Sipil Dalam Jabatan di Lingkungan Kementerian Perhubungan, dan Peraturan Menteri Perhubungan No. 4 Tahun 2019 tentang Perubahan Kedua Atas Peraturan Menteri Perhubungan Nomor PM 128 Tahun 2016 Tentang Pengangkatan Pegawai Negeri Sipil Dalam Jabatan Di Lingkungan Kementerian Perhubungan.

Keempat, evaluasi aspek rekrutmen CPNS di Kementerian Perhubungan dari dimensi keterlibatan pemangku kepentingan dalam implementasi kebijakan. Kementerian Perhubungan, KemenPANRB, dan BKN terlibat dalam rekrutmen CPNS. Semuanya berkolaborasi untuk menyeleksi pelamar-pelamar sehingga menerima pelamar yang terbaik.

Sesuai Peraturan Pemerintah Republik Indonesia Nomor 11 Tahun 2017 tentang Manajemen Pegawai Negeri Sipil, Pasal 17 ayat (1) dijelaskan bahwa dalam rangka menjamin obyektifitas pengadaan PNS secara nasional, Menteri membentuk panitia seleksi nasional pengadaan PNS, dan pada ayat (2) Panitia seleksi nasional pengadaan PNS sebagaimana dimaksud pada ayat (1) diketuai oleh Kepala BKN.

Kelima, evaluasi aspek rekrutmen CPNS dari dimensi perencanaan implementasi dan mobilisasi sumber daya. Bagi Kementerian Perhubungan sendiri, terkait dimensi ini tidak terlalu dibebani analisis yang mengarahkan pada perlunya keterampilan dan pelatihan baru untuk menerapkan kebijakan baru. Hal tersebut lebih dibebakan kepada panitia seleksi nasional yang diketuai Kepala BKN.

Keenam, evaluasi aspek rekrutmen CPNS dari dimensi operasi dan layanan. Seleksi Administrasi dilakukan secara online, dengan kriteria kelulusan didasarkan pada hasil verifikasi dokumen yang telah diunggah (upload) oleh pelamar sesuai dengan persyaratan pendaftaran. Setelah dilakukan verifikasi berkas administrasi, diperoleh sejumlah pelamar 
yang dinyatakan lulus seleksi administrasi dan sejumlah pelamar dinyatakan tidak lulus administrasi. Bagi pelamar yang dinyatakan lulus seleksi administrasi akan mengikuti Tes Kompetensi Dasar (TKD) dan Seleksi Kompetensi Bidang (SKB). TKD dilaksanakan oleh panselnas. Sementara Tes SKB dilakukan oleh Kementerian Perhubungan. Hasil pelaksanaan Tes SKB dikirim ke Panselnas untuk dilakukan Integrasi Nilai antara Nilai SKD dan SKB dengan Perbandingan Bobot Nilai yaitu Nilai SKD 40\% dan Nilai SKB 60\%. Dari hasil pengintegrasian nilai yang dilakukan oleh Tim Panselnas diperoleh sejumlah pelamar yang dapat diterima menjadi CPNS. Dalam hal ini, terjadi mekanisme koordinasi, sistem operasional, dan kapasitas individu dan organisasi yang terjadi antara panselnas dengan Kementerian Perhubungan.

Ketujuh, evaluasi aspek rekrutmen CPNS di Kementerian Perhubungan dari dimensi umpan balik tentang kemajuan dan hasil. Tujuan dari rekrutmen CPNS adalah mendapatkan talenta terbaik. Implementasi rekrutmen CPNS di lingkungan Kementerian Perhubungan dinilai lebih transparan pasca implementasi UU ASN. Kementerian Perhubungan telah melaksanakan rekrutmen pegawai menggunakan Computer Assisted Test (CAT).

\section{b. Evaluasi Penerimaan Calon Taruna}

Jalur kedua yang dapat dijadikan sebagai alternatif untuk menjadi ASN di Kementerian Perhubungan adalah jalur pembibitan atau penerimaan calon taruna.

Pertama, evaluasi aspek rekrutmen Calon Taruna di Kementerian Perhubungan dari dimensi kebijakan, perumusannya, dan penyebarannya. Rekrutmen calon taruna di sekolahsekolah yang berada di bawah wewenang Badan Pengembangan Sumber Daya Manusia Perhubungan dimaksudkan untuk menciptakan SDM Transportasi yang profesional serta memberikan kesempatan kepada seluruh masyarakat Indonesia untuk dididik menjadi Taruna Transportasi sehingga dapat memenuhi lapangan kerja. Tujuan dari penerimaan calon taruna adalah untuk menciptakan tenaga transportasi yang memiliki kompetensi dibidangnya, dapat memenuhi kebutuhan tenaga kerja di bidang transportasi secara maksimal, dan turut serta dalam upaya mencerdaskan bangsa pada bidang transportasi. Dari segi tujuan, sasaran, dan strategi, maka hal tersebut sudah sesuai dengan masalah yang harus ditangani oleh kebijakan. Apa yang dilakukan oleh Kementerian Perhubungan dapat mengatasi persoalan link and match dunia pendidikan dengan industri selama ini.

Kedua, evaluasi aspek rekrutmen Calon Taruna di Kementerian Perhubungan dari dimensi konteks sosial, politik, dan ekonomi. Geografis Indonesia yang terhampar dari Sabang sampai Merauke mengharuskan adanya ruang yang mengakomodir semua kalangan dari berbagai suku bangsa untuk menjadi bagian dari pembangunan transportasi di Indonesia. 
ARTIKEL

Dengan konteks sosial yang demikian, maka rekrutmen calon taruna memberikan solusi atas hal tersebut. Secara politis, hal ini juga mempengaruhi rasa persatuan dari seluruh elemen bangsa di Indonesia. Dalam konteks ekonomi, pengaruh untuk memajukan daerah dengan direkrutmen calon-calon taruna dari daerah menjadi hal yang mendasari penyelenggaraan rekrutmen calon taruna.

Ketiga, evaluasi aspek rekrutmen Calon Taruna di Kementerian Perhubungan dari dimensi kepemimpinan untuk implementasi kebijakan. Menteri dan pejabat di lingkungan Kementerian Perhubungan mendukung pola pembibitan ini melalui rekrutmen calon taruna. Hal itu dikarenakan banyaknya kebutuhan di bidang industri yang harus dipenuhi. Terlebih lagi kebutuhan kompetensi yang dimaksud bersifat spesifik.

Keempat, evaluasi aspek rekrutmen Calon Taruna di Kementerian Perhubungan dari dimensi keterlibatan pemangku kepentingan dalam implementasi kebijakan. Badan Pengembangan Sumber Daya Manusia Perhubungan menjadi pihak yang berwenang dan terlibat langsung dalam rekrutmen calon taruna di sekolah-sekolah yang berada di bawah pengawasannya.

Kelima, evaluasi aspek rekrutmen Calon Taruna dari dimensi perencanaan implementasi dan mobilisasi sumber daya. Penerimaan calon taruna bukan merupakan sesuatu yang baru setelah diterapkannya UU ASN. Sebelum UU ASN terbit, penerimaan calon taruna telah terselenggara. Oleh karena itu, terkait hal ini tidak ada analisis yang mengarahkan pada perlunya keterampilan dan pelatihan baru untuk menerapkan kebijakan baru.

Keenam, evaluasi aspek rekrutmen Calon Taruna dari dimensi operasi dan layanan. Rekrutmen calon taruna di sekolah-sekolah yang berada di bawah Badan Pengembangan Sumber Daya Manusia Perhubungan dilakukan dengan menyelenggarakan beberapa tes, yaitu Tes Potensi Akademik berbasis Computer Assisted Test (CAT), Psikotes, Tes Kesehatan, Test Wawancara dan Tes Kesamaptaan serta Penentuan Terakhir. Koordinasi dan sistem operasi tetap sama selama periode tahun 2015-2019.

Ketujuh, evaluasi aspek rekrutmen Calon Taruna di Kementerian Perhubungan dari dimensi umpan balik tentang kemajuan dan hasil. Setiap tahunnya rekrutmen calon taruna menghasilkan calon taruna sesuai dengan yang ditentukan baik dari segi jumlah maupun kualitas calon taruna. 
ARTIKEL

\section{Evaluasi Aspek Pengembangan Kompetensi ASN di Kementerian Perhubungan}

Pengembangan kompetensi ASN menurut UU ASN dapat dilakukan melalui 2 (dua) cara, yaitu pendidikan dan pelatihan. Sebagai standar evaluasi pada aspek pengembangan kompetensi di Kementerian Perhubungan, penelitian ini menggunakan 7 dimensi dan indikator yang sekaligus merupakan model konseptual jika menggunakan istilah yang ada dalam metode SSM. Nantinya, akan dijelaskan satu per satu dari dimensi yang digunakan untuk mengevaluasi aspek pengembangan kompetensi ASN di Kementerian Perhubungan.

a. Evaluasi Pendidikan

Pendidikan artinya ASN tersebut akan mengikuti proses pendidikan sehingga mencapai degree. Istilah yang digunakan oleh Kementerian Perhubungan terkait pendidikan ini adalah Rintisan Gelar S2/S3. Penjelasan mengenai evaluasi pendidikan ASN Kementerian Perhubungan adalah sebagai berikut.

Pertama, evaluasi pendidikan ASN di Kementerian Perhubungan dari dimensi kebijakan, perumusannya, dan penyebarannya. Kebijakan mengenai pendidikan ASN merupakan bagian dari arah pengembangan kompetensi ASN di Kementerian Perhubungan yang mana arah tersebut terlihat sangat menonjol dibandingkan dengan aspek perencanaan dan rekrutmen. Untuk meningkatkan skill manajemen dan pola pikir yang global, pendidikan ASN ini menjadi solusi atas tantangan yang dihadapi organisasi di era globalisasi ini.

Kedua, evaluasi pendidikan ASN di Kementerian Perhubungan dari dimensi konteks sosial, politik, dan ekonomi. Tidak cukup terlihat adanya faktor sosial dan politik yang mempengaruhi implementasi pendidikan ASN di Kementerian Perhubungan. Faktor yang lebih mempengaruhi adalah faktor ekonomi atau dalam konteks ini berupa anggaran Kementerian Perhubungan yang menjadi landasan perhitungan target lulusan ASN yang mengikuti pendidikan.

Ketiga, evaluasi pendidikan ASN di Kementerian Perhubungan dari dimensi kepemimpinan untuk implementasi kebijakan. Diantara periode 2015-2019, tahun 2015 menunjukkan target lulusan yang lebih banyak dibandingkan dengan tahun-tahun lainnya. Dukungan pimpinan untuk tahun 2015 lebih tinggi dibandingkan dengan tahun 2016-2019. Pada tahun 2015, target lulusan ASN yang menempuh pendidikan S2/S3 adalah 137 orang, sementara pada tahun 2016 berjumlah 24 orang, tahun 2017 berjumlah 47 orang, tahun 2018 berjumlah 47 orang, dan tahun 2019 berjumlah 73 orang. Namun demikian, apabila melihat trend target lulusan S2/S3 dari tahun 2016 sampai dengan 2019 menunjukkan peningkatan.

Keempat, evaluasi pendidikan ASN di Kementerian Perhubungan dari dimensi keterlibatan pemangku kepentingan dalam implementasi kebijakan. Badan Pengembangan 
ARTIKEL

Sumber Daya Manusia Perhubungan menjadi pihak yang berwenang dan mengawasi dalam hal pendidikan ASN ini. Kampus-kampus yang menjadi tempat ASN menempuh pendidikan menjadi pihak lain yang terlibat. Unit kerja menjadi pemangku kepentingan utama dari pendidikan ASN ini karena mengharapkan lulusan yang bisa berkontribusi pada peningkatan kinerja unit kerjanya.

Kemudian yang ke 2 adalah kelembagaan manajemen talenta, nah nanti kami juga akan berkolaborasi dengan bapenas, dengan bkn, dengan lan gitu ya. Dengan ksn kaitan dengan kelembagaan manajemen talenta.

Kelima, evaluasi pendidikan ASN di Kementerian Perhubungan dari dimensi perencanaan implementasi dan mobilisasi sumber daya. Pendidikan ASN merupakan hal yang sudah lama dilakukan. oleh karena itu, tidak ada yang terlalu signifikan untuk dievaluasi dalam hal dimensi ini.

Keenam, evaluasi pendidikan ASN di Kementerian Perhubungan dari dimensi operasi dan layanan. Sekretariat Badan Pengembangan SDM Perhubungan melaksanakan kegiatan Rintisan Pendidikan Gelar S2/S3 dalam rangka menciptakan SDM Aparatur Perhubungan yang berkualitas dan kompeten di bidangnya. ASN yang menempuh pendidikan adalah ASN yang terpilih melalui proses seleksi.

Ketujuh, evaluasi pendidikan ASN di Kementerian Perhubungan dari dimensi umpan balik tentang kemajuan dan hasil. Pada tahun 2015, dari target 137 lulusan yang terealisasi sebanyak 109 lulusan atau persentase ketercapaiannya adalah 79,56\%. Pada tahun 2016, dari target 24 lulusan yang terealisasi melampaui target yaitu mencapai 42 lulusan atau tingkat ketercapaiannya adalah 175\%. Pada tahun 2017, dengan target 47 lulusan, jumlah yang terealisasi adalah 44 lulusan atau 94\%. Pada tahun 2018 kondisinya sama dengan tahun 2017. Adapun pada tahun 2019, dari target lulusan yang berjumlah 73 lulusan, jumlah yang terealisasi hanya 38 lulusan.

b. Evaluasi Pelatihan

Adapun pelatihan adalah berbagai macam peningkatan skill yang akan diterima oleh ASN. Penjelasan mengenai pelatihan ASN Kementerian Perhubungan adalah sebagai berikut.

Pertama, evaluasi pelatihan ASN di Kementerian Perhubungan dari dimensi kebijakan, perumusannya, dan penyebarannya. Kebijakan mengenai pelatihan ASN seperti pendidikan ASN sebelumnya merupakan bagian dari arah pengembangan kompetensi ASN di Kementerian Perhubungan yang mana arah tersebut terlihat sangat menonjol dibandingkan dengan aspek perencanaan dan rekrutmen. Untuk meningkatkan skill teknis dan manajerial, pelatihan ASN ini menjadi solusi atas tantangan yang dihadapi unit organisasi. 
ARTIKEL

Kedua, evaluasi pelatihan ASN di Kementerian Perhubungan dari dimensi konteks sosial, politik, dan ekonomi. Sama halnya dengan pendidikan ASN, tidak cukup terlihat adanya faktor sosial dan politik yang mempengaruhi implementasi pendidikan ASN di Kementerian Perhubungan. Faktor yang lebih mempengaruhi juga adalah faktor ekonomi atau dalam konteks ini berupa anggaran Kementerian Perhubungan yang menjadi landasan perhitungan jumlah pelatihan dan peserta pelatihan.

Ketiga, evaluasi pelatihan ASN di Kementerian Perhubungan dari dimensi kepemimpinan untuk implementasi kebijakan. Pimpinan di Kementerian Perhubungan mendukung implementasi pelatihan ASN dengan meningkatkan anggaran pelatihan dari tahun ke tahun. Selain itu, unit kerja juga mendukung setiap ASN yang bertugas di unit kerja terkait untuk mengikuti pelatihan.

Keempat, evaluasi pelatihan ASN di Kementerian Perhubungan dari dimensi keterlibatan pemangku kepentingan dalam implementasi kebijakan. Badan Pengembangan Sumber Daya Manusia Perhubungan menjadi pihak yang berwenang dalam melaksanakan pelatihan bagi ASN. Selain itu, unit kerja juga dalam konteks tertentu melaksanakan pelatihan-pelatihan yang dibutuhkan oleh ASN. Sama halnya dengan konteks pendidikan ASN, unit kerja menjadi pemangku kepentingan utama dari pelatihan ASN ini karena mengharapkan adanya peningkatan kinerja baik secara individu maupun untuk unit kerja terkait.

Kelima, evaluasi pelatihan ASN di Kementerian Perhubungan dari dimensi perencanaan implementasi dan mobilisasi sumber daya. Jika pendidikan ASN merupakan hal yang sudah lama dilakukan, lain halnya dengan pelatihan karena terus berkembang. Hal yang menjadi permasalahan berkelanjutan adalah menentukan jenis pelatihan apa yang diperlukan oleh ASN. Oleh karena itu, peta atau profil kompetensi ASN di Kementerian Perhubungan menjadi penting. Pada tahun 2015, sebetulnya telah terbit Peraturan Menteri Perhubungan No. 81 Tahun 2015 tentang Profil Kompetensi Individu di Lingkungan Kemenhub. Akan tetapi, implementasi dan outputnya masih belum koheren dengan kebutuhan pelatihan yang perlu diikuti ASN Kementerian Perhubungan. Dalam konteks pihak yang berwenang membuat pedoman pengembangan kompetensi pun saat ini masih dalam proses penyusunan di Lembaga Administrasi Negara dalam bentuk manajemen talenta.

Keenam, evaluasi pelatihan ASN di Kementerian Perhubungan dari dimensi operasi dan layanan. Badan Pengembangan SDM Perhubungan menyelenggarakan beberapa pelatihan untuk ASN Kementerian Perhubungan, diantaranya Pelatihan Struktural /Kepemimpinan, Pelatihan Fungsional, Pelatihan Teknis/Manajerial, dan Pengembangan dan 
ARTIKEL

Peningkatan Kapasitas Sumber Daya Manusia Perhubungan. Dalam operasioanlnya, Pelatihan Prajabatan dimaksudkan untuk meningkatkan peningkatan pengetahuan, keahlian, keterampilan dan sikap untuk dapat melaksanakan tugas secara profesional dalam melaksanakan tugas pemerintah. Pelatihan Struktural/ Kepemimpinan dimaksudkan untuk mencapai persyaratan kompetensi kepemimpinan aparatur pemerintah yang sesuai dengan jabatan structural eselon tertentu, serta memiliki kesamaan pola pikir yang dinamis dan bernalar agar memiliki wawasan pengetahuan yang komprehensif dan semangat pengabdian yang berorientasi kepada pelayanan prima serta pengembangan partisipasi masyarakat.

Ketujuh, evaluasi pelatihan ASN di Kementerian Perhubungan dari dimensi umpan balik tentang kemajuan dan hasil. Terkait pelatihan struktural/kepemimpinan, pada tahun 2015 dari target lulusan sebanyak 282 orang, jumlah realisasinya adalah 277 lulusan atau 98,23\%. Pada tahun 2016, dengan menetapkan target 152 lulusan, realisasi lulusan yang tercapai adalah 149 lulusan atau 98,03\%. Pada tahun 2017, dari target lulusan sebanyak 96 orang, jumlah yang terealiasi adalah 93 lulusan atau 96,9\%. Pada tahun 2018, dari target lulusan sebanyak 96 orang, jumlah yang terealiasi adalah 93 lulusan atau 96,9\%. Pada tahun 2019, capaian target lulusan sebanyak 1.281 orang peserta dari target 1.286 orang peserta dengan persentase $99.61 \%$.

\section{KESIMPULAN}

Dengan berjalannya perencanaan, rekrutmen, dan pengembangan kompetensi ASN dalam kurun 5 (lima) tahun pasca terbitnya Undang-Undang ASN, penelitian ini mengevaluasi implementasinya dari 7 (tujuh) dimensi, yaitu kebijakan, perumusannya, dan penyebarannya, konteks sosial, politik, dan ekonomi, kepemimpinan untuk implementasi kebijakan, (4) keterlibatan pemangku kepentingan dalam implementasi kebijakan, perencanaan implementasi dan mobilisasi sumber daya, operasi dan layanan, dan umpan balik tentang kemajuan dan hasil.

Aspek rekrutmen menunjukkan masih ada yang perlu dibenahi terutama dalam rekrutmen CPNS di Kementerian Perhubungan. beberapa permasalahan teknis terkait rekrutmen CPNS masih terjadi. Instansi yang diteliti masih perlu meluruskan makna dan arah kebijakan rekrutmen sehingga sesuai dengan apa yang diamanatkan oleh UU ASN. Adapun terkait seleksi terbuka, menjunjung sistem merit harus dikedepankan sehingga tidak terjadi politisasi birokrasi. Secara prosedur, dari ketujuh dimensi yang dijadikan alat evaluasi menunjukkan bahwa di kedua instansi tersebut telah melaksanakannya sesuai prosedur. 
ARTIKEL

Perbaikan dan peningkatan masih diperlukan dalam prosesnya sehingga dapat terwujud rekrutmen yang objektif dan terpilih talenta-talenta terbaik.

Aspek pengembangan kompetensi menunjukkan bagian yang prioritas dan mendapat perhatian lebih dari Kementerian Perhubungan dibandingkan aspek perencanaan dan rekrutmen. Tantangan untuk meningkatkan kinerja organisasi, efisiensi penggunaan anggaran belanja pegawai, dan berbagai arah kebijakan nasional menyebabkan aspek pengembangan kompetensi ini menjadi aspek yang mendapat perhatian lebih. Meskipun dari segi hasil masih perlu diukur apakah dapat meningkatkan kinerja organisasi, terjadi efisiensi anggaran, dan tercapainya arah pembangunan nasional.

\section{DAFTAR PUSTAKA}

Ahmadi, S. A. A., Salamzadeh, Y., Daraei, M., \& Akbari, J. (2012). Relationship Between Organizational Culture and Strategy Implementation: Typologies and Dimensions. Global Business and Management Research, 4(3/4), 286.

Aspinall, E. (2019). Conclusion: Social Movements, Patronage Democracy, and Populist Backlash in Indonesia. Activists in Transition: Progressive Politics in Democratic Indonesia, 187-201.

Baron, A., \& Armstrong, M. (2007). Human Capital Management: Achieving Added Value Through People. Kogan Page Publishers.

Basuki, J. (2006). Budaya Organisasi Konsep dan Terapan, Yayasan Pembinaan Manajemen. Jakarta: Arta Teras Media.

Becker, B. E., Huselid, M. A., Huselid, M. A., \& Ulrich, D. (2001). The HR Scorecard: Linking People, Strategy, and Performance. Harvard Business Press.

Becker, B., \& Gerhart, B. (1996). The Impact of Human Resource Management on Organizational Performance: Progress and Prospects. Academy of management Journal, 39(4), 779-801.

Blunt, P., Turner, M., \& Lindroth, H. (2012). Patronage's Progress in Post-Soeharto Indonesia. Public Administration and Development, 32(1), 64-81.

Bushardt, S. C., Glascoff, D. W., \& Doty, D. H. (2011). Organizational culture, formal reward structure, and effective strategy implementation: A conceptual model. Journal of Organizational Culture, Communication and Conflict, 15(2), 57-71.

Checkland, P., \& Holwell, S. (1998). Action research: its nature and validity. Systemic practice and action research, 11(1), 9-21.

Fathoni, A. (2019). Organisasi dan Manajemen Sumber Daya Manusia. Jakarta: Rineka Cipta

Friedman, B. A. (2007). Globalization Implications for Human Resource Management Roles. Employee Responsibilities and Rights Journal, 19(3), 157-171. 
Handoko, T. H. (2001). Manajemen Personalia dan Sumber Daya Manusia. Yogyakarta: BPFE.

Hardjosoekarto, S. (2012). Soft Systems Methodology (Metode Serba Sistem Lunak). Penerbit Universitas Indonesia (UI-Press).

Hasibuan, M. S. (2005). Manajemen Sumber Daya Manusia. Jakarta: Bumi Aksara.

Indonesia, L. A. N. R. (2017). Manajemen ASN: Modul Pelatihan Dasar Calon PNS. Jakarta: Lembaga Administrasi Negara.

Komisi Aparatur Sipil Negara. (2018). Penilaian Penerapan Sistem Merit dalam Manajemen ASN di Instansi Pemerintah Tahun 2018. Jakarta: KASN.

McKay, J., \& Marshall, P. (2001). The Dual Imperatives of Action Research. Information Technology \& People.

Morley, M., Valverde, M., Ryan, G., \& Soler, C. (2006). Distributing HRM responsibilities: a classification of organisations. Personnel Review.

Oktarina, A., \& Mustam, M. (2018). Manajemen sumber daya aparatur sipil negara (ASN) dalam rangka reformasi birokrasi di badan kepegawaian pendidikan dan pelatihan daerah (BKPPD) Kota Pekalongan. Journal of Public Policy and Management Review, 7(2), 40-54.

Prasojo, E. (2006). Reformasi Kepegawaian di Indonesia. Jurnal Ilmiah Administrasi Publik, III (1), 419-420.

Stavrou, E. T., \& Brewster, C. (2005). The Configurational Approach to Linking Strategic Human Resource Management Bundles with Business Performance: Myth or Reality?. Management Revue, 186-201.

Uchiyama, K. (2009). Preliminary discussion of Validity and Legitimacy of SSM-based AR. Action research for improvement in schools, communities and organizational spaces What is to be done?, 67.

Yuniarsih, \& Suwatno. (2008). Manajemen Sumber Daya Manusia. Bandung: Alfabeta. 